\title{
PENGARUH FAKTOR CIRI KEPRIBADIAN DAN KEPRIBADIAN MEREK TERHADAP LOYALITAS MEREK SMARTPHONE OPPO
}

\author{
Nuniek Tri Yuntanti, Agus Suroso, Refius Pradipta Setyanto \\ Magister Manajemen, Universitas Jenderal Soedirman Indonesia \\ e-mail : nuniek3yuntanti@gmail.com
}

\begin{abstract}
Abstrak
Tujuan penelitian adalah untuk menganalisis hubungan antara ciri kepribadian dan kepribadian merek serta pengaruh ciri kepribadian dan kepribadian merek terhadap loyalitas merek pengguna smartphone Oppo. Penelitian ini merupakan penelitian kuantitatif dan diklasifikasikan dalam penelitian asosiatif. Metode penelitian ini adalah survey dengan sampel adalah pengguna smartphone Oppo di wilayah Purwokerto. Jumlah sampel dalam penelitian ini adalah sebanyak 200 sampel dengan metode pengambilan sampel yang digunakan adalah non-probability sampling dengan teknik purposive sampling. Pengujian statistik yang dilakukan adalah menggunakan analisis regresi linier berganda sedangkan untuk pengujian hubungan antara variabel ciri kepribadian dan kepribadian merek menggunakan analisis korelasi Pearson. Hasil analisis menunjukkan bahwa sebagian ciri kepribadian berhubungan positif signifikan dengan kepribadian merek, kepribadian merek berpengaruh positif terhadap loyalitas merek, namun ciri kepribadian tidak berpengaruh terhadap loyalitas merek smartphone Oppo.

Kata Kunci : ciri kepribadian, kepribadian merek, loyalitas merek
\end{abstract}

\begin{abstract}
The purpose of the study was to analyze the relationship between personality traits and brand personality and the influence of personality traits and brand personality on the brand loyalty of Oppo smartphone users. This research is quantitative research and classified in associative research. This research method is a survey with samples of Oppo smartphone users in the Purwokerto area. The number of samples in this study was 200 samples with the sampling method used was non-probability sampling with purposive sampling technique. Statistical testing is done using multiple linear regression analysis while for testing the relationship between variables of personality traits and brand personality using Pearson correlation analysis. The analysis shows that some personality traits are significantly positively related to brand personality, brand personality has a positive effect on brand loyalty, but personality traits have no effect on Oppo smartphone brand loyalty.

Keywords: personality traits, brand personality, brand loyalty
\end{abstract}

\section{PENDAHULUAN}

Saat ini persaingan dalam dunia usaha komunikasi semakin berkembang. Masuknya pasar global membawa dampak dalam berbagai sisi perekonomian. Informasi merupakan suatu hal yang wajib bagi masyarakat untuk mengetahui perkembangan dunia. Saat ini teknologi informasi dan komunikasi menjadi suatu hal yang mengalami perkembangan pesat di tengah masyarakat yang semakin heterogen dengan latar belakang budaya yang berbeda beda. 
Perkembangan pasar produk smartphone sebagai akibat dari perkembangan bisnis komunikasi juga mengalami kemajuan yang sangat pesat di Indonesia. Indonesia sebagai negara berkembang dengan budaya masyarakatnya yang juga beraneka ragam menjadi lahan potensial produsen smartphone untuk mengenalkan produk produknya yang mengalami inovasi secara terus menerus mengikuti permintaan konsumennya. Masyarakat Indonesia yang responsif dan serba ingin tahu menjadi alasan juga perkembangan bisnis smartphone ini. Smartphone yang saat ini beredar bukan hanya digunakan sebagai sarana komunikasi saja, namun juga menjadi alat pemenuh kebutuhan untuk memperoleh informasi tentang banyak hal disamping juga sebagai gaya hidup, menunjukkan kelas sosial atau gengsinya pada kelompok masyarakat lain.

Salah satu merek baru yang cukup mendapat posisi di pasar konsumen Indonesia adalah smartphone merek Oppo. Merek ini dipilih sebagai desain sampling penelitian karena menurut riset IDC (International Data Corporation) tahun 2017, walaupun pangsa pasar smartphone di Indonesia masih dikuasai Samsung (30\%), namun Oppo sebagai merek baru mampu menempati posisi kedua dengan capaian sebesar 25,5\% diikuti Advan 8,3\%, Vivo 7,5\% dan Xiaomi di 5,2\%. Pada tahun 2016 salah satu seri Oppo yaitu F1 dan F1 plus juga meraih penghargaan sebagai The Best Camera Smartphone pada Selular Award 2016. Pencapaian Oppo juga tidak hanya berskala nasional namun juga global. Pada 2016 Oppo menempati posisi ke empat sebagai produsen smartphone di pangsa pasar dunia berdasarkan data IDC. Di kalangan pengamat Oppo dikenal sebagai brand baru yang sukses mencuri pasar.

Banyak faktor internal dan faktor eksternal yang harus dimiliki perusahaan agar bertahan hidup dan bergerak maju dalam kondisi persaingan tersebut. Masuknya berbagai hal yang inovatif dan kondisi pasar yang jenuh untuk produk produk tertentu, menjadi salah satu tantangan bagi manager pada abad 21 untuk memahami hubungan antara loyalitas dan variabel yang mempengaruhinya (Taylor et al., 2004). Menurut penelitian yang dilakukan Kim et al (2017) variabel yang mempengaruhi loyalitas merek antara lain adalah ciri kepribadian konsumen, yang dimediasi oleh kepuasan serta kesesuaian. Menurut penelitian Lin (2010) dengan sampel konsumen pada merek video game meneliti variabel-variabel yang mempengaruhi loyalitas adalah ciri kepribadian konsumen dan kepribadian merek. Penelitian Temouri et al (2016) juga menunjukkan bahwa kepribadian merek menjadi faktor yang mempengaruhi loyalitas.

Penelitian ini berangkat dari rekomendasi penelitian sebelumnya dari Lin (2010) yang mencatat bahwa belum banyak peneliti yang menyelidiki pengaruh secara simultan antara ciri kepribadian konsumen dan loyalitas merek, sehingga variabel ini menarik untuk diteliti kembali. Disamping penelitian ini juga dilakukan karena terdapat riset gap yaitu perbedaan hasil pada penelitian-penelitian sebelumnya antara lain penelitian yang dilakukan Lin (2010) yang mendukung sebagian hipotesis yang menyatakan bahwa ciri kepribadian (openness dan 
agreeableness) berpengaruh positif signifikan terhadap loyalitas merek, Trevor A Smith (2015) menyatakan ciri kepribadian (conscientiousness, neuroticism, extroversion dan openness) berpengaruh positif signifikan dengan loyalitas dan Aghapour et al (2016) dengan hasil dimensi ciri kepribadian berpengaruh pada loyalitas. Namun hasil berbeda diperoleh dimana penelitian berikutnya yang dilakukan oleh Kim et al (2017) menyatakan bahwa dimensi ciri kepribadian tidak berpengaruh terhadap loyalitas merek.

Melihat riset gap berupa perbedaan hasil dan rekomendasi dari penelitian sebelumnya, maka penelitian ini mencoba mengembangkan penelitian sebelumnya dengan meneliti hubungan antara semua dimensi dalam variabel ciri kepribadian yaitu openness, conscientiousness, extroversion, agreeableness, dan neuroticism dengan seluruh dimensi dalam kepribadian merek yaitu sincerity, excitement, sophistication, competence dan ruggedness. Dan meneliti pengaruh antara ciri kepribadian dan kepribadian merek dengan loyalitas merek.

\section{TINJAUAN PUSTAKA}

\section{Loyalitas merek}

Loyalitas pelanggan terhadap merek produk merupakan konsep yang sangat penting khususnya pada kondisi tingkat persaingan yang tinggi. Untuk dapat bertahan perusahaan harus memiliki konsumen yang loyal yang bersedia membeli produk-produk yang dihasilkan oleh perusahaan. Eisman (1990) mendefinisikan loyalitas tindakan sebagai suatu kepuasan konsumen dengan pembelian merek tertentu secara reguler. Definisi loyalitas merek juga diusulkan oleh Jacoby dan Olson (1970). Mereka mendefinisikan loyalitas merek sebagai hasil dari kegiatan non-acak, respon perilaku, dan hal tersebut merupakan proses pembelian mental yang dibentuk oleh beberapa unit keputusan tertentu. Day (1969) menjelaskan loyalitas merek terdiri dari tindakan pembelian berulang yang didorong oleh perintah internal yang kuat. Dari sudut pandang ini, pembelian dilakukan bukan karena sikap yang kuat namun hanya bersifat situasional. Klasifikasi konsep silang yang dikembangkan sebelumnya sikap relatif dengan patronase berulang mengarah pada empat kondisi spesifik terkait dengan loyalitas yang diklasifikasikan oleh teori Dick dan Basu (1994) sebagai :

1. Loyalitas sejati (true loyalty)

2. Loyalitas palsu (spurious loyalty)

3. Loyalitas tersembunyi (latent loyalty)

4. Tidak ada loyalitas (no loyalty)

Pada penelitian sebelumnya peneliti biasanya menggunakan tindakan pembelian kembali sebagai metode mengukur loyalitas merek. Namun dalam penelitian terbaru, beberapa peneliti mengindikasikan untuk cara untuk mengukur loyalitas merek adalah dengan mengukur loyalitas afektif (Bennett dan Rundle-Thiele, 2000). Penelitian kali ini menggunakan konsep loyalitas 
merek dari Chaudhori dan Hoolbrook (2001), mereka menyatakan behavioral loyalty sebagai purchase loyalty.

\section{Ciri kepribadian}

Gordon Allport, seorang psikolog Amerika dan pendiri psikologi kepribadian, menggambarkan kepribadian adalah sebagai "orang yang nyata." Selain itu Allport menyatakan bahwa kepribadian merupakan organisasi dinamis sistem psikofisiologis yang menciptakan pola perilaku, pemikiran, dan perasaan seseorang (Allport, 1961). Teori kepribadian dapat dibagi menjadi dua pendapat (Lin, 2010). Pendapat pertama percaya bahwa semua individu memiliki ciri yang sama, namun perbedaannya hanya pada tingkatan masing-masing sifat. Sedangkan pendapat yang lain percaya bahwa varians individu berasal dari kombinasi sifat, yang mana bervariasi dari satu orang ke orang lain, sehingga setiap orang memiliki pilihannya sendiri secara spesifik (Sternberg, 2000). Penelitian ini mengacu pada teori kepribadian dari Mc Crae et al (1986) yang mengklasifikasikan ciri kepribadian menjadi lima bagian yaitu extroversion, agreeableness, conscientiousness, neuroticism dan openness. Lima faktor tersebut umumnya disebut sebagai Big Five Model yang banyak digunakan pada penelitian saat ini. Dimensi kepribadian Big-Five adalah puncak penelitian lebih dari 40 tahun tentang emosional, interpersonal, pengalaman, sikap dan motivasi individu (Zhao dan Seibert, 2006).

\section{Kepribadian merek}

Definisi dari kepribadian merek adalah "himpunan karakteristik manusia yang terkait dengan merek" (Aaker, 1997). Penelitian penelitian berikutnya yang mempelajari perilaku konsumen, memberi perhatian yang cukup besar pada konstruk kepribadian merek, yang mengacu pada kumpulan karakteristik manusia yang terkait dengan merek. Peneliti telah memusatkan perhatian pada bagaimana kepribadian merek bisa menjelaskan ekspresi diri seseorang (Belk, 1988), konsep diri ideal bagi seseorang (Malhotra, 1988), atau dimensi diri secara spesifik (Kleine dan Keman, 1993) melalui penggunaan merek. Pengamat memandangnya sebagai cara utama untuk membedakan merek dalam kategori produk (Halliday, 1996), sebagai pusat perhatian konsumen (Biel, 1993), dan dapat digunakan untuk memasarkan merek (Plummer, 1985). Aaker (1997) menggunakan psikologi kepribadian untuk mengembangkan "skala kepribadian merek,". Skala kepribadian terdiri dari lima dimensi yaitu excitement, competence, sincerity, sophistication, dan ruggedness. Kepribadian merek yang berbeda memainkan peran kunci dalam kesuksesan merek. Ini mengarahkan pelanggan untuk memahami kepribadian merek. Dan mengembangkan hubungan yang kuat dengan merek (Doyle, 1990). 


\section{PERUMUSAN HIPOTESIS}

\section{Hubungan Ciri Kepribadian dengan Kepribadian Merek}

Konsumen akan memiliki preferensi terhadap produk yang memiliki tingkat kesesuaian yang tinggi antara konsep diri mereka sendiri dan kepribadian merek. Dimensi kepribadian adalah variabel berguna dalam memeriksa pilihan merek konsumen. Karena merek yang sukses biasanya sesuai dengan kepribadian konsumen (Lin, 2010). Beberapa penelitian sebelumnya seperti penelitian yang dilakukan Guo (2003) memberikan hasil yang menyatakan ada korelasi yang signifikan antara ciri kepribadian sesuai dengan Model Lima Dimensi Big Five Personality dan kepribadian merek. Hubungan antara ciri kepribadian dan kepribadian merek juga diteliti oleh Chow et al (2004) dengan obyek penelitian terhadap mahasiswa yang membeli sepatu olahraga. Secara empiris, hasil penelitian ini konsisten dengan temuan studi sebelumnya dari Imanikhah et al (2013) yang juga menyatakan bahwa ciri kepribadian berhubungan positif dengan kepribadian merek. Dengan mengklasifikasikan merek-merek yang disukai, penelitian menemukan bahwa dengan ciri kepribadian yang berbeda menunjukkan perbedaan yang signifikan pula dalam preferensi kepribadian merek. Dari ulasan hasil penelitian tersebut diatas dapat ditarik hipotesis sebagai berikut:

H1 : Terdapat hubungan positif antara ciri kepribadian dengan kepribadian merek

\section{Hubungan Ciri Kepribadian dengan Loyalitas Merek}

Secara empiris, terdapat temuan studi yang dilakukan oleh Smith (2015) bahwa ciri kepribadian berpengaruh positif dan signifikan terhadap loyalitas. Hasil penelitian ini konsisten pula dengan temuan studi Matzler et al (2006) yang menyelidiki hubungan antara ciri kepribadian, nilai hedonis, brand affection dan brand loyalty. Hasilnya menunjukkan bahwa ciri kepribadian tertentu memiliki pengaruh positif pada loyalitas merek atau produk dan nilai hedonis. Berdasarkan hasil tersebut ditarik hipotesis sebagai berikut :

H2 : Ciri kepribadian berpengaruh positif terhadap loyalitas merek

\section{Hubungan Kepribadian Merek dengan Loyalitas Merek}

Mengxia (2007) meneliti pengaruh kepribadian merek pada preferensi merek konsumen, loyalitas dan niat beli. Hasilnya menunjukkan bahwa kepribadian merek memiliki pengaruh positif terhadap preferensi merek, loyalitas dan niat beli. Hasil penelitian yang dilakukan oleh Brakus et. al. (2009) menyatakan kepribadian merek yang memuat dimensi sincerity, competence, excitement, sophistication dan ruggedness memiliki pengaruh pada loyalitas. Penelitian Cleff et. al. (2013) berikutnya menunjukkan bahwa dimensi kepribadian merek juga berpengaruh positif terhadap loyalitas merek. Berdasarkan hasil tersebut ditarik hipotesis sebagai berikut :

H3 : Kepribadian merek berpengaruh positif terhadap loyalitas merek 


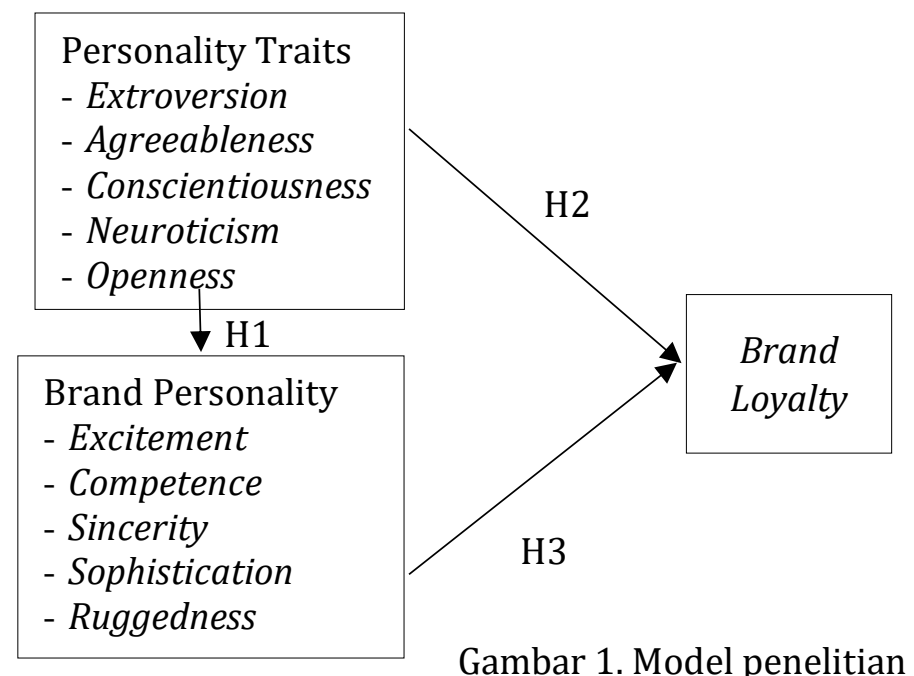

\section{METODE PENELITIAN}

Penelitian ini merupakan penelitian survey yang di lakukan di Purwokerto dan dapat diklasifikasikan kedalam penelitian asosiatif/hubungan. Sampel diambil dari para pengguna smartphone Oppo dengan kriteria minimal telah menggunakan smartphone dengan merek yang sama selama 1 (satu) tahun. Kriteria ini digunakan dengan pertimbangan bahwa menurut data survey yang dilakukan oleh Lembaga Riset MARS dan diiniasi oleh produsen merek lokal, hampir $80 \%$ pengguna smartphone di Indonesia mengganti perangkat smartphone mereka dalam kurun waktu dua tahun. MARS menemukan hasil 29,7\% responden mengganti perangkat smartphone mereka dalam waktu 1,5 - 2 tahun, 27,8\% mengganti perangkat smartphone dalam waktu 1 - 1,5 tahun dan 20,6\% responden saja yang mengganti smartphone lama mereka dengan yang baru dalam kurun waktu setelah lebih dari dua tahun. Sedangkan sisanya sebanyak 21,9\% mengganti smartphone mereka dalam waktu kurang dari satu tahun. Jumlah sampel dibulatkan menjadi 200, yang difokuskan kepada para pekerja yang dibagi dalam 4 wilayah kecamatan di kota Purwokerto masing masing sebanyak 50 sampel di wilayah Kecamatan Purwokerto Timur, Purwokerto Barat, Purwokerto Selatan dan Purwokerto Utara. Teknik pengambilan sampling menggunakan Non- Probability Sampling dengan teknik Purposive sampling. Desain sampling pada penelitian ini adalah merk smartphone Oppo.

Penyusunan instrument dalam penelitian ini berasal dari penelitian sebelumnya yang mengadopsi jurnal internasional. Skala pengukuran dalam penelitian menggunakan skala Likert 5 point $(1=$ sangat tidak setuju, $5=$ sangat setuju). Untuk menguji hipotesis hubungan antar variabel menggunakan alat analisis Korelasi Pearson, sedangkan untuk menguji pengaruh antar variabel menggunakan alat analisis regeresi berganda. 


\section{HASIL DAN PEMBAHASAN}

Deskripsi responden

Kuesioner yang disebarkan sebanyak 220, setelah dilakukan pemilihan terhadap hasil responden, didapat hasil yang sesuai estimasi yaitu sebanyak 200 kuesioner yang layak untuk dianalisis. Pelaksanaan penelitian dimulai pada minggu pertama bulan Juni 2018 sampai dengan batas akhir pengembalian yakni minggu kedua bulan Juli 2018.

Tabel 1. Karakteristik Responden berdasarkan jenis kelamin

\begin{tabular}{c|c|c}
\hline Jenis Kelamin & Frekuensi & Persentase (\%) \\
\hline Pria & 93 & 46,5 \\
Wanita & 107 & 53,5 \\
\hline TOTAL & 200 & $100 \%$ \\
\hline
\end{tabular}

Tabel 2. Karakteristik Responden berdasarkan usia

\begin{tabular}{c|c|c}
\hline Usia & Frekuensi & Persentase (\%) \\
\hline$<30$ & 63 & 31,5 \\
$30-50$ & 117 & 58,5 \\
$>50$ & 20 & 10 \\
\hline TOTAL & 200 & $100 \%$ \\
\hline
\end{tabular}

Tabel 3. Karakteristik Responden berdasarkan tingkat pendidikan

\begin{tabular}{c|c|c}
\hline Tingkat Pendidikan & Frekuensi & Persentase (\%) \\
\hline SMP & 6 & 3 \\
D3 & 33 & 16,5 \\
SMA & 50 & 25 \\
S1 & 90 & 45 \\
S2 & 21 & 10,5 \\
\hline TOTAL & 200 & $100 \%$ \\
\hline
\end{tabular}

Tabel 4. Karakteristik Responden berdasarkan tingkat pendapatan

\begin{tabular}{c|c|c}
\hline Tingkat Pendapatan & Frekuensi & Persentase (\%) \\
\hline$<1$ juta & 11 & 5,5 \\
$1-5$ juta & 152 & 76 \\
$5-7$ juta & 18 & 9 \\
$>7$ juta & 19 & 9,5 \\
\hline TOTAL & 200 & $100 \%$ \\
\hline
\end{tabular}

Sumber : Data diolah

Semua item pertanyaan kuesioner dari masing-masing variabel dalam penelitian ini memiliki koefisien korelasi $\left(r_{\text {hitung }}\right.$ ) yang lebih besar dari nilai $r_{\text {tabel }}=0,374$, sehingga kuesioner terbukti valid dan dapat digunakan sebagai alat pengumpul data. Pengujian reliabilitas kuesioner dalam penelitian menggunakan rumus Cronbach's Alpha. Koefisien reliabilitas ( $\mathrm{r}_{\text {total }}$ ) variabel personality traits $\left(\mathrm{X}_{1}\right)$, brand personality $\left(\mathrm{X}_{2}\right)$, dan $\left(\mathrm{r}_{\text {total }}\right)$ variabel brand loyalty $(\mathrm{Y})$ masing-masing lebih besar dari cut of value $(0,60)$ sehingga semua pertanyaan untuk setiap variabel dalam penelitian ini dinyatakan reliabel dan dapat digunakan sebagai alat pengumpulan data. 
Hasil Analisis Korelasi Pearson

Tabel 5. Ringkasan Hasil Analisis Korelasi Pearson

\begin{tabular}{|r|l|r|r|r|r|r|}
\hline & Dimensi & Sincerity & Excitement & Sophistication & Ruggedness & \multicolumn{1}{c|}{ Competence } \\
\hline 1 & Ekstraversion & $0,172^{* *}$ & $0,240^{* *}$ & $-0,113$ & 0,048 & $0,139^{*}$ \\
\hline 2 & Neuroticism & $-0,146^{*}$ & $-0,113$ & $0,219^{* *}$ & $-0,093$ & $-0,055$ \\
\hline 3 & Conscientiousness & 0,035 & $0,189^{* *}$ & $-0,077$ & $0,181^{* *}$ & 0.097 \\
\hline 4 & Agreeableness & 0,024 & $0,158^{*}$ & 0,102 & 0.072 & $0,254^{* *}$ \\
\hline 5 & Openess & $-0,052$ & $-0,003$ & $0,127^{*}$ & 0,072 & $0,144^{*}$ \\
\hline
\end{tabular}

Sumber : Data diolah

Dari tabel diketahui bahwa ciri kepribadian ekstraversion berhubungan positif signifikan dengan kepribadian merek sincerity sebesar 0,172 dengan excitement sebesar 0,240 dan dengan kepribadian merek competence 0,139. Ciri kepribadian ekstroversion tidak berhubungan dengan kepribadian merek ruggednes. Neuroticism berhubungan positif signifikan dengan kepribadian merek sophistication sebesar 0,219 dan tidak berhubungan dengan kepribadian merek ruggednes, excitement dan competence. Ciri kepribadian neuroticism juga signifikan namun berhubungan negatif dengan kepribadian merek sincerity. Ciri kepribadian conscientiousness berhubungan positif signifikan dengan excitement sebesar 0,189, ruggednes sebesar 0,181 dan tidak berhubungan dengan kepribadian merek sincerity, sophistication maupun kepribadian merek competence. Ciri kepribadian agreeableness berhubungan positif signifikan dengan kepribadian merek excitement 0,158 dan competence sebesar 0,254. Namun agreeableness tidak berhubungan dengan kepribadian merek sincerity, sophistication dan ruggednes. Ciri kepribadian Openess tidak berhubungan dengan kepribadian merek sincerity, excitement dan ruggednes namun berhubungan positif signifikan dengan kepribadian merek sophistication sebesar 0,127 dan competence 0,144. Dengan demikian, maka hipotesis pertama yang menyatakan bahwa terdapat hubungan yang positif antara ciri kepribadian dengan kepribadian merek sebagian diterima.

Tabel 6. Ringkasan Hasil Analisis Regresi Berganda

\begin{tabular}{|c|l|c|c|c|c|}
\hline No. & \multicolumn{1}{|c|}{ Variabel } & Koefisien Regresi & $t_{\text {hitung }}$ & & $\begin{array}{c}t_{\text {tabel }} \\
\text { (one tailed })\end{array}$ \\
\hline 1 & Ciri kepribadian $\left(\mathrm{X}_{1}\right)$ & 0,039 & 1,335 & $<$ & 1,660 \\
2 & Kepribadian merek $\left(\mathrm{X}_{2}\right)$ & 0,394 & 4,157 & $>$ & 1,660 \\
\hline
\end{tabular}

Konstanta $=-2,484$

$R^{2}$ Square $=0,232$

$\mathrm{F}_{\text {hitung }}=19,750$

Sumber : Data diolah

Dari persamaan tersebut dapat dijelaskan konstanta sebesar -2,484 yang berarti jika variabel ciri kepribadian dan kepribadian merek tidak ada perubahan atau sama dengan nol, maka loyalitas merek akan mengalami penurunan sebesar 2,484 satuan.

Pengujian signifikansi pengaruh variabel ciri kepribadian dan kepribadian merek terhadap loyalitas merek secara parsial dilakukan dengan uji t. Berdasarkan tingkat kesalahan $(\alpha)=0,05$ dan degree of freedom $(n-k)$, dimana $n=200$ dan $k=4$, maka dapat diketahui nilai 
$t_{\text {tabel }}$ untuk pengujian satu sisi (one tailed) sebesar 1,660. Adapun dari output analisis regresi

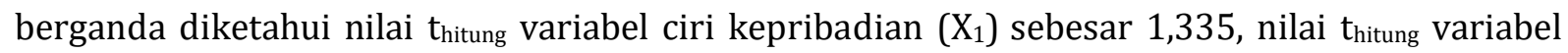
kepribadian merek $\left(\mathrm{X}_{2}\right)$ sebesar 4,157 . Hasil analisis regresi berganda menunjukkan bahwa nilai

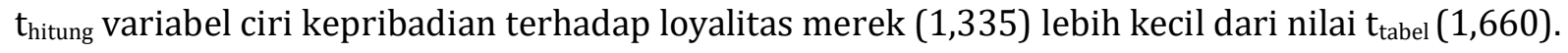
Hasil uji tersebut menunjukkan bahwa secara parsial ciri kepribadian mempunyai pengaruh yang positif namun tidak signifikan terhadap loyalitas merek. Dengan demikian, hipotesis kedua yang menyatakan bahwa ciri kepribadian berpengaruh positif terhadap loyalitas merek ditolak. Nilai $t_{\text {hitung }}$ variabel kepribadian merek terhadap loyalitas merek $(4,157)$ lebih besar dari nilai

$t_{\text {tabel }}(1,660)$. Menunjukkan bahwa kepribadian merek berpengaruh positif dan signifikan terhadap loyalitas merek. Dengan demikian, maka hipotesis ketiga yang menyatakan bahwa kepribadian merek berpengaruh positif terhadap loyalitas merek diterima.

\section{PEMBAHASAN}

Penelitian sebelumnya dari Lin (2010) hanya mencari hubungan antara variabel ciri kepribadian (extroversion, agreeableness, conscientiousness) dengan kepribadian merek (excitement, competence, dan sincerity). Penelitian ini mengembangkan penelitian tersebut dengan mencari hubungan antara seluruh dimensi variabel ciri kepribadian (extroversion, agreeableness, conscientiousness, openness dan neuriticsm) dan dimensi variabel kepribadian merek (excitement, competence, sophistication, rugedness dan sincerity). Hasil penelitian ini menunjukkan bahwa hanya sebagian ciri kepribadian yang mempunyai hubungan yang positif dan signifikan dengan variabel kepribadian merek. Terdapat koefisien korelasi yang signifikan positif antara ciri kepribadian ekstroversion dengan kepribadian merek sincerity, excitement dan competence. Seseorang dengan ciri kepribadian ekstroversion yang terbuka, mudah bergaul dan berteman, bersikap sosial, humoris akan sesuai dengan karakter kepribadian merek sincerity yang periang dan rendah hati, dalam hal ini jenis smartphone Oppo memberi kesan bukan hanya merek yang digunakan untuk kalangan atas saja, tapi bisa digunakan untuk semua kalangan misalnya Oppo seri A dan Oppo Neo, jadi lebih bersifat humble disamping tampilan produknya yang memberi kesan menyenangkan dan ceria sesuai sifat seseorang yang periang. Ekstroversion juga sesuai dengan ciri kepribadian excitement yang memiliki ciri bersemangat, modern dan berani dimana smartphone Oppo ini mencirikan merek yang apabila digunakan memberi kesan modern dan berani seperti smartphone Oppo seri F dan R9 plus karena fitur fiturnya terutama kameranya memberikan tampilan unggul dan modern yang disesuaikan dengan gaya hidup masyarakat saat ini yang suka mengabadikan setiap momen dalam kegiatannya. Fitur yang ada dalam smartphone Oppo tipe ini juga mendukung berbagai aplikasi-aplikasi kekinian yang mengikuti perkembangan trend yang berlaku di masyarakat. Kepribadian merek competence yang berciri sukses dan dapat diandalkan seperti smartphone Oppo yang saat ini sukses merebut 
pangsa pasar karena inovasi inovasinya, dan dapat diandalkan karena fitur fitur terbarunya yang ditawarkan akan sesuai dengan seseorang yang memiliki kepribadian ekstroversion tersebut yang antara lain suka berpikir, suka memberi saran dan dapat mengontrol diri sehingga dapat diandalkan oleh kelompok/lingkungannya.

Korelasi positif signifikan juga terdapat antara ciri kepribadian neuroticism dengan kepribadian merek sophistication, antara conscientiousness dengan kepribadian merek excitement dan ruggednes. Hal ini dapat disimpulkan dimana ciri kepribadian neuroticism yang antara lain suka membandingkan dirinya sendiri dengan orang lain, bangga dan puas terhadap dirinya sendiri, akan sesuai dengan smartphone Oppo yang berciri kepribadian merek yang apabila digunakan memberi kesan sebagai smartphone bagi kalangan atas dengan tampilan produk yang menawan sesuai dengan ciri sophistication seperti tipe Oppo R7 series. Conscientiousness yang memiliki sifat mandiri, aspirasi tinggi, suka berkhayal, akan sesuai dengan jenis smartphone Oppo yang bercirikan kepribadian excitement yang imaginatif seperti pada Oppo tipe F5 yang memiliki fitur beauty recognition technology dimana fitur ini merupakan pengembangan Oppo atas banyaknya perangkat lunak pada smartphone yang menerapkan percantik wajah. Dengan fitur ini kamera pada Oppo F5 dapat mengaplikasikan hasil yang berbeda antara pria dan wanita meskipun dalam satu frame. Conscientiousness yang suka mempertahankan diri, memiliki motivasi besar dalam dirinya juga akan berhubungan positif signifikan dengan kepribadian merek ruggedness yang antara lain memiliki sifat tangguh seperti jenis smartphone Oppo terbaru tipe R9s.

Hubungan positif signifikan juga terdapat antara hubungan ciri kepribadian agreeableness dengan excitement dan competence, serta antara ciri kepribadian openess dengan kepribadian merek sophistication dan competence. Hal ini dapat dijelaskan bahwa seseorang dengan ciri agreeableness yang simpatik, penuh pertimbangan, hangat dan suka memberi akan sesuai dengan kepribadian merek excitement yang berciri bersemangat dan berani yang sesuai dengan Oppo tipe Mirror , dan dengan kepribadian merek competence yang berciri merek yang dapat diandalkan seperti Oppo tipe F dan R.

Hubungan signifikan negatif terdapat dalam hubungan antara ciri kepribadian neuroticism dan kepribadian merek sincerity. Sedangkan ciri kepribadian ekstroversion tidak berhubungan dengan kepribadian merek sophistication, dan ruggedness. Ciri kepribadian neuroticism tidak berhubungan dengan kepribadian merek excitement, ruggednes dan competence. Conscientiousness juga tidak berhubungan dengan kepribadian merek sincerity, sophistication, dan competence. Agreeableness tidak berhubungan dengan sincerity, sophistication, dan ruggednes. Sedangkan ciri kepribadian berikutnya yaitu openess tidak berhubungan dengan ciri kepribadian sincerity, excitement dan ruggednes. 
Hubungan tersebut menunjukkan bahwa ciri kepribadian seseorang dengan keunikannya masing-masing terbukti memiliki hubungan dengan kepribadian merek tertentu pula dimana kepribadian merek disini diasumsikan sebagai sekumpulan karakterisitik manusia yang terkait dengan merek. Dimana kepribadian merek tersebut diharapkan dapat merepresentasikan keinginan konsumen akan produk yang sesuai dengan kepribadian mereka sendiri. Secara empiris, hasil penelitian ini konsisten dengan temuan studi sebelumnya dari Guo (2003) dan juga penemuan Lin (2010) yang juga menemukan bukti bahwa terdapat korelasi yang signifikan antara sebagian ciri kepribadian dengan kepribadian merek. Penemuan Imanikhah et al (2013) juga menyatakan bahwa ciri kepribadian konsumen berhubungan positif dengan kepribadian merek.

Ciri kepribadian mempunyai pengaruh yang positif namun tidak signifikan terhadap loyalitas merek. Hubungan kausal tersebut mengindikasikan bahwa semakin baik ciri kepribadian konsumen tidak selalu diikuti dengan semakin tingginya tingkat loyalitas konsumen terhadap merek. Hal ini dikarenakan ciri kepribadian konsumen adalah sesuatu yang sangat variatif dan unik. Secara umum seseorang akan mewarisi ciri kepribadian secara genetis, namun hal ini tidak mutlak karena kepribadian seseorang dapat berubah karena banyak faktor yang mempengaruhi, seperti tingkat pendidikan, pergaulan maupun budaya. Hal ini akan mempengaruhi cara pandang atau sikap mereka terhadap banyak hal termasuk loyalitas terhadap suatu merek. Secara empiris, hasil penelitian ini berbeda dengan temuan studi yang dilakukan oleh Smith (2015) bahwa ciri kepribadian berpengaruh positif dan signifikan terhadap loyalitas. Di sisi lain, hasil penelitian ini konsisten dengan temuan studi yang diakukan oleh Kim et al., (2017) yang juga menunjukkan bukti bahwa dimensi ciri kepribadian tidak berpengaruh signifikan terhadap loyalitas merek.

Hasil penelitian ini membuktikan bahwa kepribadian merek mempunyai pengaruh yang positif dan signifikan terhadap loyalitas merek. Hubungan kausal tersebut menunjukkan bukti bahwa semakin baik kepribadian merek, maka akan semain tinggi tingkat loyalitas konsumen terhadap merek yang bersangkutan. Produk yang memiliki kepribadian merek yang baik atau sesuai dengan ekspektasi konsumen akan menimbulkan ikatan yang kuat antara konsumen dan merek tersebut yang selanjutnya menciptakan loyalitas merek. Hasil penelitian ini sejalan dengan temuan penelitian sebelumnya yang dilakukan oleh Mengxia (2007), Kumar, dkk., (2006), Brakus et. al. (2009) dan selanjutnya penelitian Cleff et. al. (2013) yang menunjukkan bahwa dimensi kepribadian merek juga berpengaruh positif terhadap loyalitas merek.

\section{KESIMPULAN}

Hasil penelitian menunjukkan bahwa sebagian ciri kepribadian berhubungan positif signifikan dengan kepribadian merek. Yaitu ekstraversion berhubungan positif signifikan dengan 
kepribadian merek sincerity, excitement dan dengan kepribadian merek competence. Ciri kepribadian neuroticism berhubungan positif signifikan dengan kepribadian merek sophistication. Ciri kepribadian conscientiousness berhubungan positif signifikan dengan kepribadian merek excitement dan ruggednes. Ciri kepribadian agreeableness berhubungan positif signifikan dengan kepribadian merek excitement dan competence. Ciri kepribadian Openess berhubungan positif signifikan dengan kepribadian merek sophistication dan competence. Hal ini dapat disimpulkan bahwa semakin beragamnya karakteristik konsumen, maka produsen merek smartphone Oppo juga harus memiliki inovasi yang beragam pula baik secara desain, fitur, dan aplikasinya agar dapat memenuhi keinginan konsumen yang variatif sesuai dengan ciri kepribadian masing-masing.

Selanjutnya analisa data penelitian menunjukkan bahwa ciri kepribadian dan kepribadian merek berpengaruh positif signifikan dengan loyalitas merek, hal ini dapat digunakan sebagai acuan bagi produsen merek smartphone Oppo untuk mengkreasikan berbagai variasi fitur maupun desain berdasarkan kepribadian merek yang berbeda sebagai upaya untuk meningkatkan loyalitas konsumen. Disamping itu smartphone Oppo dalam upaya terus meningkatkan dan mempertahankan loyalitas pelanggannya, perlu memperhatikan berbagai kebijakan pemasaran. Terkait dengan beberapa keterbatasan dalam penelitian ini, maka penelitian selanjutnya perlu menambahkan variabel-variabel bebas lainnya. Jika dimungkinkan penelitian selanjutnya juga perlu melakukan pengembangan model penelitian dengan menambahkan variabel intervening dan moderasi misalnya variabel kepuasan (satisfaction). Peneliti selanjutnya juga perlu memperluas cakupan penelitian agar hasil penelitian nantinya dapat lebih obyektif dan dapat digeneralisasikan.

\section{DAFTAR PUSTAKA}

Aaker. 1997. Dimensions of Brand Personality. Journal of Marketing Research Vol 34(3): 347 356.

Aghdaie, Karimi1 \& Abasaltian. 2015. The Evaluation of Effect Electronic Banking in Customer Satisfaction and Loyalty. International Journal of Marketing Studies Vol 7(2).

Akin. 2017. The Impacts of Brand Personality on Brand Loyalty: A Research on Automobile Brands in Turkey. International Journal of Marketing Studies Vol 9(2).

Brakus, J.J.,Schmitt, B.H \& Zarantonello, L. 2009. Brand Experience : What is it? How is it Meassured? Does it Affect Loyalty? Journal of Marketing. Vol.73(2).

Cleff et. al. 2013. Brand Experience-How It Relates to Brand Personality, Consumer Satisfaction And Consumer And Consumer Loyalty. An Empirical Analysis Of The Adidas Brand. Interdisciplinary Management Research. 
Chaudhuri \& Holbrook. 2001. The chain of effects from brand trust and brand affect to brand performance ; The role of brand loyalty. Journal of Marketing.

Dant et al. 2013. Influence of Personality Traits on perceived relationship quality within a franchise - franchisor context. Europan Journal of Marketing, Vol 47(1/2): 279 - 302.

Dick \& Basu. 1994. Customer loyalty : Toward an integrated conceptual framework. Journal of the Academy of Marketing Science, Vol 22(2): 99-113.

Ghorbani \& Mousavi. 2014. The study impact of consumer personality traits on brand personality and brand loyalty (Case study : product group of Isfahan Iran Khodro. International Journal of Academic Research in Bussiness and Social Sciences, Vol 4 (1).

Hasiri \& Afghanapour. 2016. Investigation of the factors affective on the loyalty of customers in banking industry in the framework of the model of personality characteristics of personel (Case study : Sepah Bank in Mazandaran Province). Procedia Economics and Finance 36, 490-501.

Hawari. 2015. How the personality of retail bank cutomers interferes with the relationship between service quality and loyalty. International Journal of Bank Marketing, Vol 33: Iss 1.

Hyun. 2017. Relationships between brand experiences, personality traits, prestige, relationship quality, and loyalty: An empirical analysis of coffeehouse brands. International Journal of Contemporary Hospitality Management, Vol 29.

Jani \& Han. 2014. Personality, satisfaction, image, ambience and loyalty testing their relationships in the hotel industry. International Journal of Hospitality Management 37, pp 11020.

Khani \& Imanikhah. 2013. The relationship of appliance consumer personality trait, brand personality, brand loyalty and brand equity in the mobil phone industry. International Journal of Fundamental Psychology and Social Sciences (IJFPSS), Vol 3(4): 63-70

Laukkanen. 2012. Brand loyalty and the role of hedonic value. Journal of Product \& Brand Management, Vol. 21: Iss (7): 529 - 537.

Lee. 2016. The Effects of Personality Traits and Congruity on Customer Satisfaction and Brand Loyalty: Evidence from Coffee Shop Customers. Advances in Hospitality and Leisure, Vol 12: pp 3 - 33.

Lin. 2010. The Relationship of Consumer Personality Trait, Brand Personality and Brand Loyalty; an empirical study of toys and video games buyers. Journal of Product \& Brand Management: 4 - 17.

Ma'amor, et al. 2016. The influence of personality traits towards quality pledge. Procedia Economics and Finance 37, : 73-79.

McCrae et al. 1986. Evaluating Comprehensivveness in personality systems : The California Q-set and the five factor model. Journal of Personality 
Perepelkin \& Brand. 2011. Personality and customer trust in community pharmacies. International Journal of Pharmaceutical and Healthcare Marketing, Vol. 5(3): 175-193.

Peterson. 1994. A Meta-Analysis of Cronbach's Coefficient Alpha. Journal of Consumer Research, Vol 21(2): 381-391.

Sahin et al. 2011. The Effects of Brand Experiences, Trust and Satisfaction on Building Brand Loyalty; An Empirical Research On Global Brands. Procedia Social and Behavioral Sciences 24, 1288-1301.

Sekhon et al . 2013. Modelling trust in service relationships: a transnational perspective. Journal of Services Marketing, Vol 27(1) : 76-86.

Smith. 2012. The personality trait predictors of brand loyalty. Academy of Bussines Research, Vol III: 6-21.

Srivastava \& Owens. 2010. Personality trait and their effect on brand commitment : An empirical investigation. The Marketing Management Journal, Vol 20: Issue (2): 15-27.

Teoumori et al. 2016. Studying the relationship between brand personality and customer loyalty : A case study of Samsung Mobil Phone. International Journal of Bussiness and Management, Vol 11(2).

Tseng. 2016. The role of salespeople in developing life insurance customer loyalty. International Journal of Retail \& Distribution Management, Vol 44: Iss 1.

Virani. 2013. Consumer personality trait, brand persona and brand loyalty: a pragmatic study of Colgate toothpaste buyer. International Journal of Humanities and Management Sciences (IJHMS), Vol 1: issue (2).

Wang. 2011. Customer loyalty and the role of relationship length. Managing Service Quality, Vol 22(1): 58-74.

Waal \& Heijden. 2016. Increasing customer loyalty and customer intimacy by improving the behavior of employees. Journal of Strategy and Managemet, Vol 9: Iss (4): 492-510. 